\title{
A MILK EPIDEMIC OF DIPHTHERIA ASSOCIATED WITH AN UDDER DISEASE OF COWS.*
}

\author{
BY ALFRED ASHBY, M.B. (Lond.), F.R.C.S. (Eng.), \\ Medical Officer of Health of Reading, Rural District of Wokingham, etc.
}

In the Rural District of Wokingham, in the county of Berks, there lie two adjoining parishes, in one of which is the compact village of Twyford, in the other the smaller and more scattered village of Ruscombe.

At the census of 1901 there were in Twyford 270 inhabited and 4 uninhabited houses, with a population of 1,106 . The corresponding figures for Ruscombe were 74 inhabited and 2 uninhabited houses, and 323 inhabitants. Those numbers probably still hold good for Ruscombe, but Twyford in 1904 had 281 inhabited houses, with an estimated population of about 1,150 .

There was a severe epidemic of diphtheria in both those places in 1904. Between February 12th and April 21st of that year there were 17 cases in 13 houses at Twyford, and 8 cases in 5 houses at Ruscombe: 17 of the patients were children from one to thirteen years of age, the other 8 were aged from eighteen to sixty-two. Three of them died, a child aged three on March 24th and a youth aged nineteen on May 2nd at Twyford, and an infant aged one on March 28th at Ruscombe. On May 31st a sister of the young man who died at Twyford, aged seventeen, was ill with diphtheria, but recovered. Up to the end of May, therefore, there had been 18 cases in 13 houses at Twyford.'

There was then an interval when the two villages were quite free from the disease until the major epidemic commenced on July 31st, when a lady living in Twyford was attacked with it; then on August 1st her sister, who was staying in the house, on the 2nd her daughter, on the 3 rd her husband, and on the 4 th her cook fell ill. Thus, within four days five inmates of the house, which is rated at $£ 32$, were attacked. The first and three of the other patients were adults, the daughter was six years old. Two other adults living in the same house were not affected.

\footnotetext{
* Read before the Home Counties Branch of the Incorporated Society of Medical Officers of Health.
} 
The first case of this outbreak in Ruscombe commenced on August 6 th, in the person of a man aged thirty-five, living in a house just outside Twyford. The number of houses primarily invaded, and the number of persons attacked by the disease from day to day, to August 26th, are given below :-

\begin{tabular}{|c|c|c|c|c|}
\hline $\begin{array}{l}\text { Date. } \\
\text { July }\end{array}$ & & & $\begin{array}{l}\text { Number of } \\
\text { Iouses first invaded. } \\
1\end{array}$ & $\ldots \quad \begin{array}{c}\text { Number of } \\
\text { Persong attacked }\end{array}$ \\
\hline August & & . . & 0 & 1 \\
\hline , & 2 & . . & 1 & 2 \\
\hline$"$ & 3 & . & 3 & 4 \\
\hline , & 4 & .. & 2 & 3 \\
\hline , & 5 & . & 1 & . \\
\hline 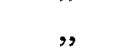 & 6 & .. & 3 & 4 \\
\hline ", & 7 & .. & 3 & . \\
\hline 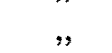 & 8 & $\therefore$ & 1 & .. \\
\hline ", & 9 & .. & 3 & .. \\
\hline & 10 & .. & 4 & . \\
\hline & 11 & .. & 0 & . \\
\hline$"$ & 12 & . & 0 & . \\
\hline$"$ & 13 & .. & 4 & . \\
\hline$"$ & 14 & .. & 0 & . \\
\hline$"$ & 15 & .. & 1 & 3 \\
\hline$"$ & 16 & .. & 4 & . \\
\hline$"$ & 17 & .. & 1 & . \\
\hline$"$ & 18 & .. & 2 & . \\
\hline$"$ & 19 & .. & 5 & .. \\
\hline$"$ & 20 & .. & 2 & .. \\
\hline$"$ & 21 & .. & 0 & .. \\
\hline$"$ & 22 & .. & 0 & .. \\
\hline$"$ & 23 & .. & 0 & .. \\
\hline$"$ & 24 & .. & 1 & .. \\
\hline$"$ & 25 & .. & 0 & .. \\
\hline$"$ & 26 & .. & 1 & . \\
\hline & & & $\overline{43}$ & $\overline{75}$ \\
\hline
\end{tabular}

The patient who was attacked on August 25th had been staying for three weeks in a house at Twyford in which another case commenced on the 24th; he returned to his home in Reading on the first-named day, and was found to be suffering from diphtheria on the 26 th.

There were multiple attacks, that is to say, two or more persons 
fell ill at the same time, or nearly so, in the same households when the houses were first invaded, in the following fourteen instances :-

July $31-$ Date.

August 3,7 and 8

$" 3$ and 6

$" 6$ and 7

, 7 and 8

$" 7$ and 8

$" 10$ and 12

" 10

, 13,

„16 and 17

„16 and 19

, 17 and 18

"20

", 24 and 25

Number of cases.

$$
\begin{array}{lll}
\ldots & \ldots & 5 \\
\ldots & \ldots & 3 \\
\ldots & \ldots & 2 \\
\ldots & \ldots & 2 \\
\ldots & \ldots & 2 \\
\ldots & \ldots & 2 \\
\ldots & \ldots & 2 \\
\ldots & \ldots & 2 \text { and } 1 \text { on Aug. } 14 \\
15, & 2 \text { cases } & 4 \\
\ldots & \ldots & 2 \\
\ldots & \ldots & 2 \\
\ldots & \ldots & 2 \text { and } 1 \text { on Aug. } 21 \\
\ldots & \ldots & 2 \\
\ldots & \ldots & 2
\end{array}
$$

\begin{tabular}{|c|c|c|c|c|}
\hline \multirow{2}{*}{$\begin{array}{l}\text { Ages- } \\
\text { Years. }\end{array}$} & \multicolumn{3}{|c|}{ Attacks. } & \multirow{2}{*}{$\begin{array}{l}\text { Fatality in each } \\
\text { age-group } \\
\text { per cent. }\end{array}$} \\
\hline & Males. & Females. & $\begin{array}{c}\text { Total } \\
\text { Attacks. }\end{array}$ & \\
\hline $0-5$ & 6 & - & 6 & - \\
\hline $5-10$ & 6 & 5 & 11 & - \\
\hline $10^{-15}$ & 5 & 5 & 10 & - \\
\hline $15-20$ & 4 & 8 & 12 & - \\
\hline $20-25$ & 4 & 6 & 10 & - \\
\hline $25-30$ & 2 & 4 & 6 & - \\
\hline $30-35$ & 3 & 2 & 5 & - \\
\hline $35-40$ & 5 & 1 & 6 & - \\
\hline $40-45$ & 1 & 2 & 3 & - \\
\hline $45-50$ & - & 1 & 1 & - \\
\hline $50-55$ & - & 1 & 1 & - \\
\hline $55-60$ & - & 二 & - & - \\
\hline $60-65$ & 1 & 2 & 3 & $33 \cdot 33$ \\
\hline 66 & 1 & - & 1 & - \\
\hline All ages & 38 & $\begin{array}{l}37 \\
\end{array}$ & 75 & $1 \cdot 33$ \\
\hline
\end{tabular}

So far, the average number of cases per infected household was 1.74, and there had been only one death, that of a patient, aged sixty-three, who lived in Twyford, but was in bad health before she was attacked with diphtheria.

The next Table shows the age and sex of the patients and the fatality of the disease :-

Only 36 per cent of the patients were under fifteen years of age, whilst 64 per cent of them were over that age; and of those 43.75 
per cent were males and 56.25 per cent were females. One male and two females were sixty-three years of age, and one male was aged sixty-six. Of the total number 38 were males and 37 were females.

Thirty-eight, or just over half of the patients, lived in houses rated at from $£ 10$ to $£ 56$, whilst 37 lived in houses rated at less than $£ 10$.

Twenty-one of the houses invaded were rated at from $£ 10$ to $£ 56$, and 22 , or just over one-half, were rated under $£ 10$.

The proportion of the total number of houses rated at $£ 10$ and upwards which were invaded amounted to 13.6 per cent, whilst only 10.9 per cent of the total number of houses rated at less than $£ 10$ were invaded.

Of the total number of inhabited houses $12 \cdot 1$ per cent were invaded.

Up to August 26th I had received notification of 75 cases in 43 houses. They were distributed as follows :-

$\begin{array}{lcccc} & & \text { In Twytord. } & & \text { In Ruscombe. } \\ \text { Number of houses invaded } & . & 35 & . & 8 \\ \text { Number of persons attacked } & . & 63 & \ldots & 12 \\ \text { Average number of cases per house } & 1 \cdot 8 & \ldots & 1.5 \\ \text { Houses invaded per cent of total hoụses } 12 \cdot 4 & \ldots & 10.8\end{array}$

Although the proportion of houses of the cottage class is greater in Ruscombe than in Twyford - the percentage of houses rated under $£ 10$ being 75 in Ruscombe and only 46 in Twyford-the proportion of the total houses invaded was less in the former than in the latter place.

Milk was supplied to the two villages by three dairymen, who may be designated by the letters $\mathrm{X}, \mathrm{Y}$, and $\mathrm{Z}$. A few houses in Ruscombe had milk from three farms in that parish.

One of the houses invaded by diphtheria was supplied by X, 15 of them were supplied by $\mathrm{Y}$ alone, 17 were supplied by $\mathrm{Z}$ alone, and 10 were supplied by both $\mathrm{Y}$ and $\mathrm{Z}$.

Of the total number of houses supplied in the two places by $\mathrm{X}, 3 \cdot 1$ per cent were invaded; of the total number supplied by $\mathrm{Y}$ alone, 6.8 per cent were invaded; and of the total number supplied by $Z$ alone, 42.5 per cent were invaded, the mixed supplies of $\mathrm{Y}$ and $\mathrm{Z}$ being left out of count altogether.

On August 12th, with the consent of $Y$ and $Z, I$ sent a sample of their milk to the Clinical Research Association, Limited, London, for bacteriological examination, for the purpose of ascertaining whether the diphtheria bacillus could be isolated from either milk; and on the 19th I sent up a sample of milk from another of Y's herds of cows for a similar examination to be made. 


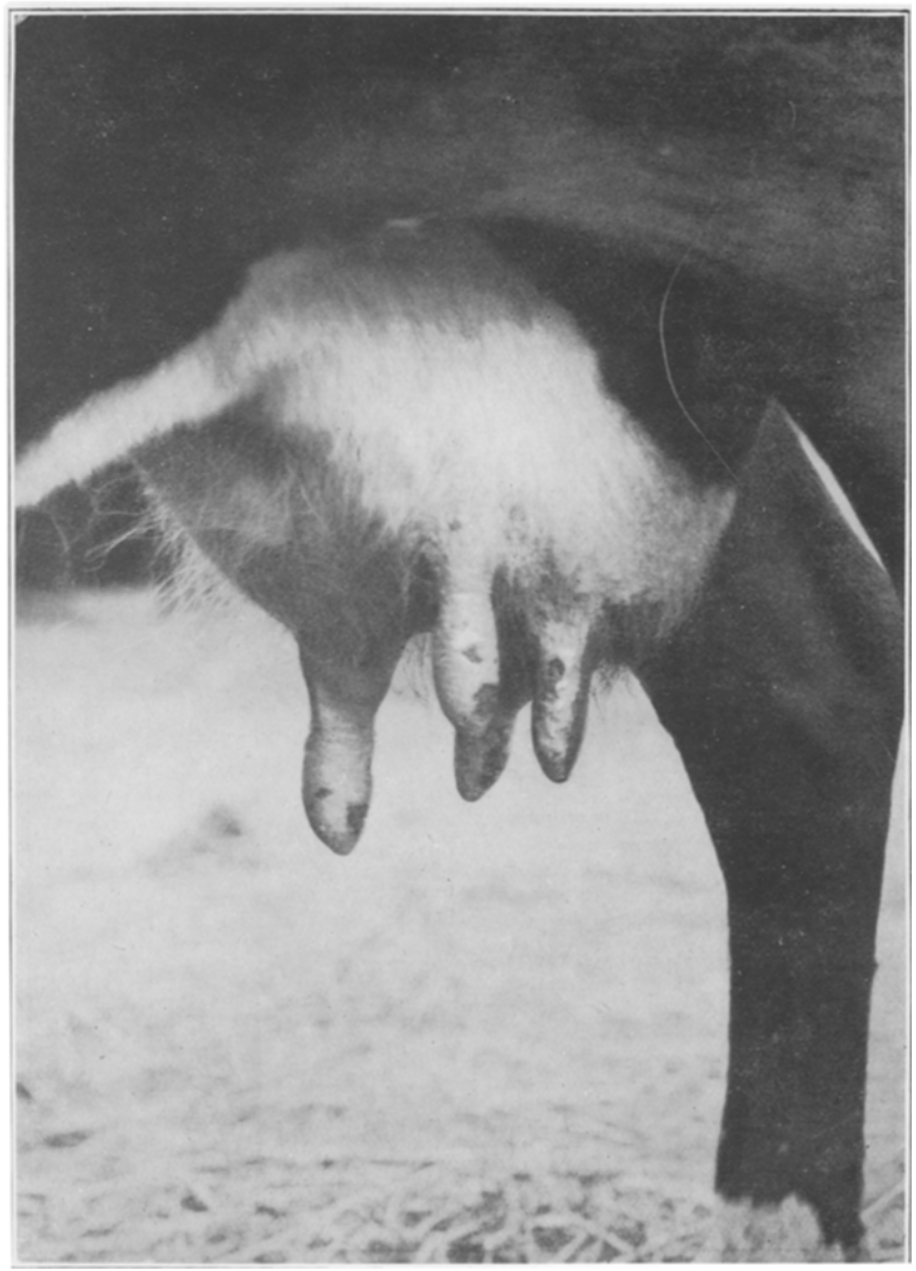

Fir. 1 is from a photograph of the left side of the adder of one of the worst fwo cows. It shows that all four teats were badly ulcerated. 


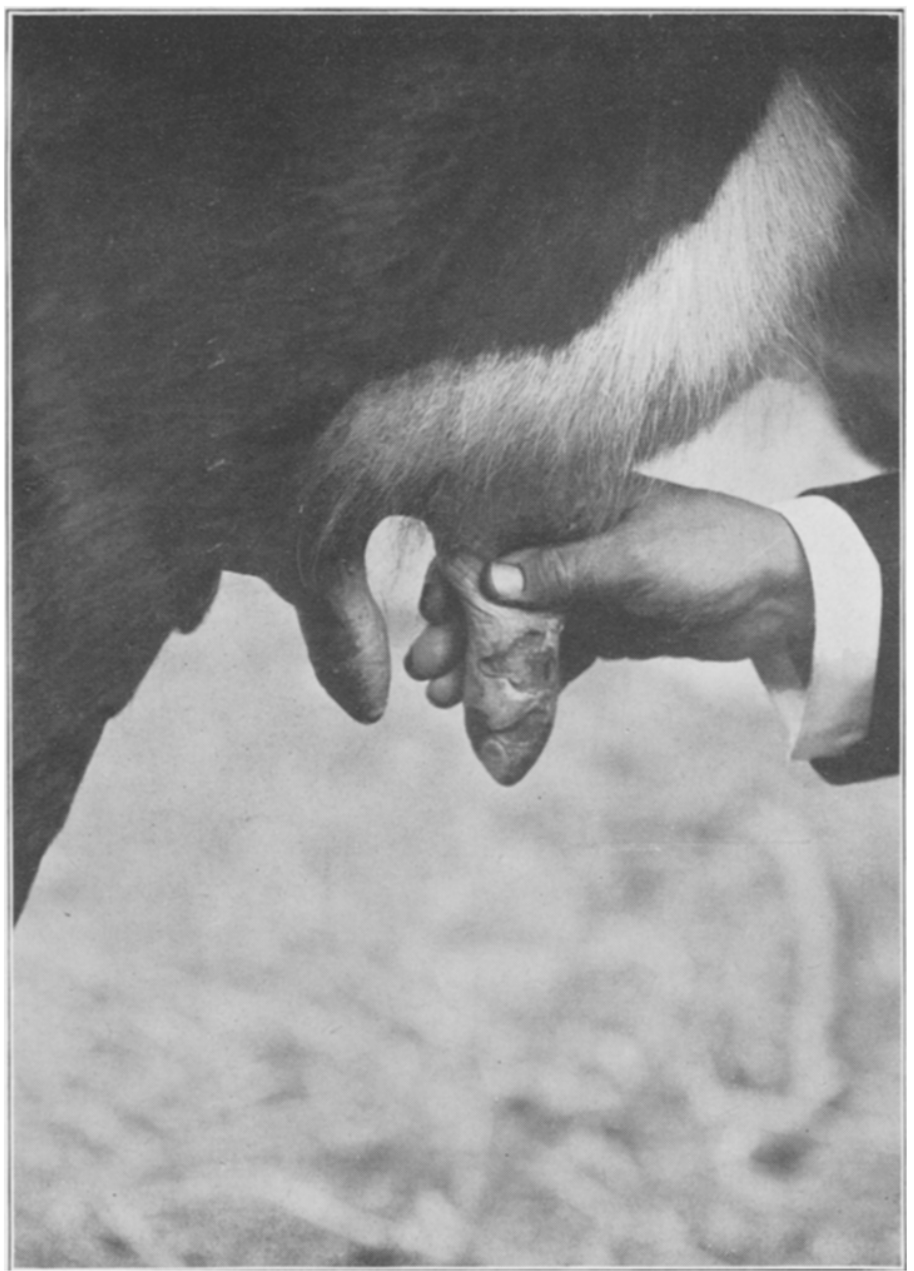

FIG. 2 represents the right side of the udder of the same cow, 


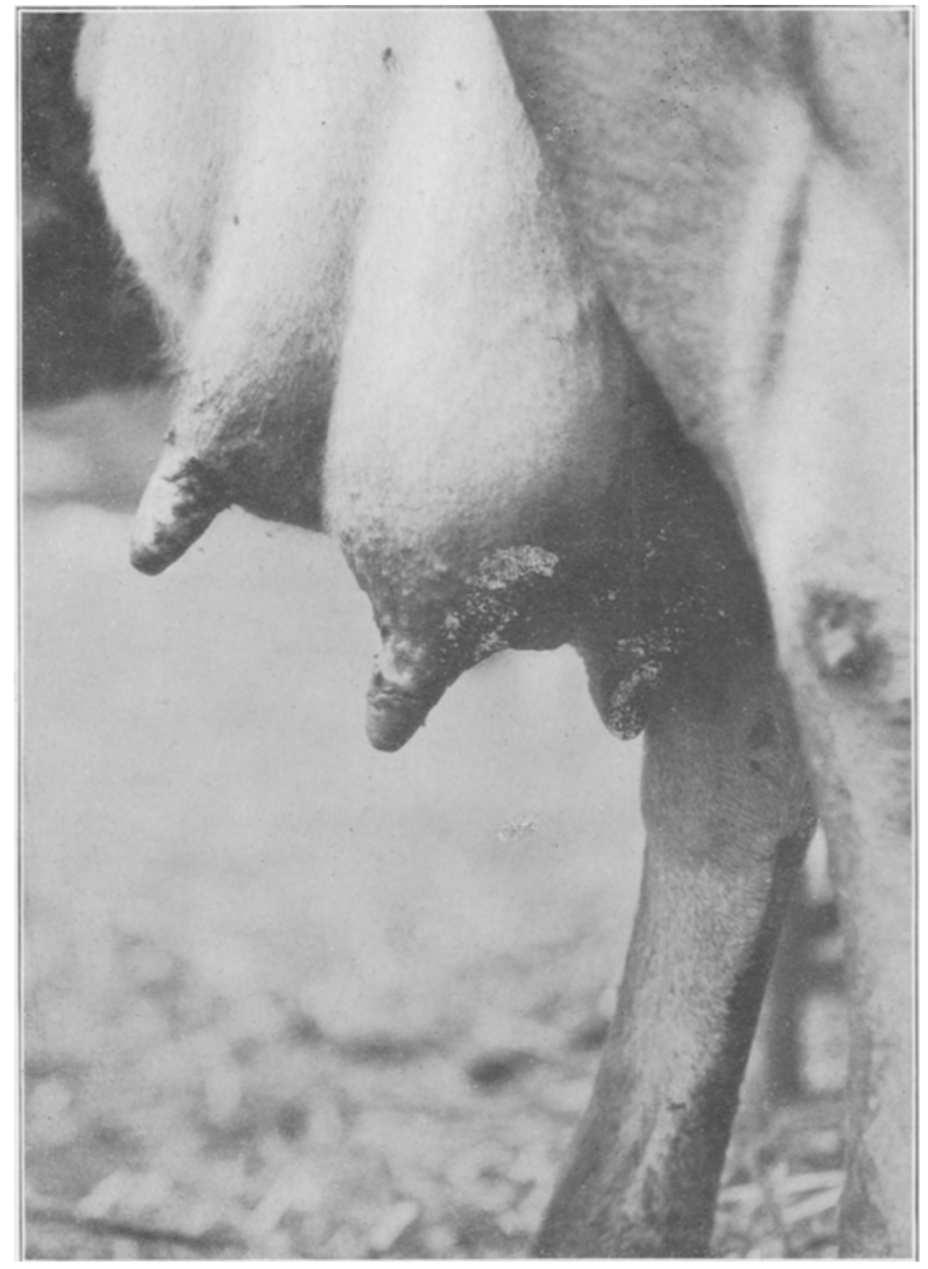

FIG. 3 shows the left side of the udder of the other of the worst two cows. 


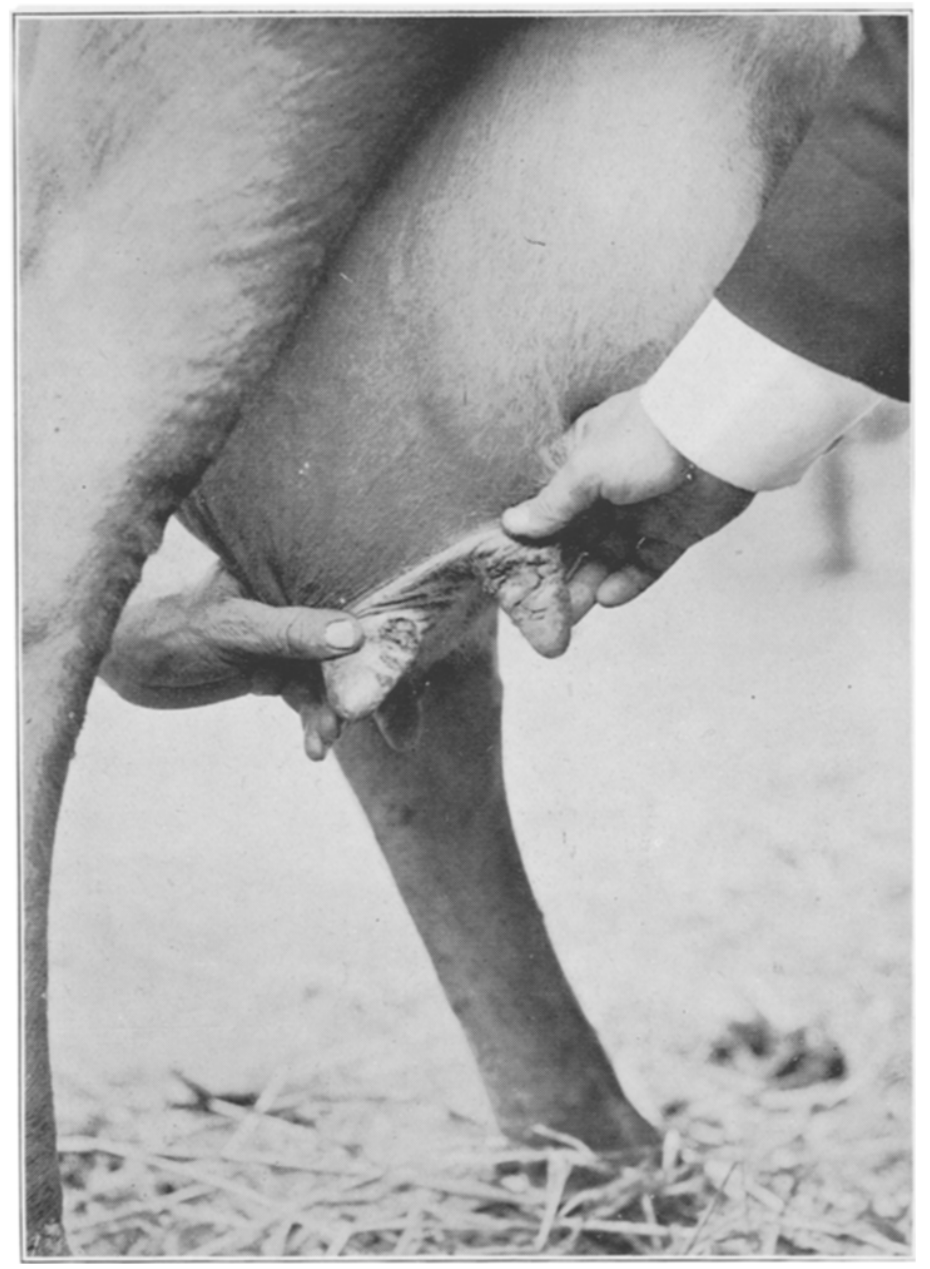

FIG. 4 is from a photograph of the right side of the udder of the same cow. FIGS. 3 and 4 together show that all forr of the teats of this cow were badly ulcerated. 


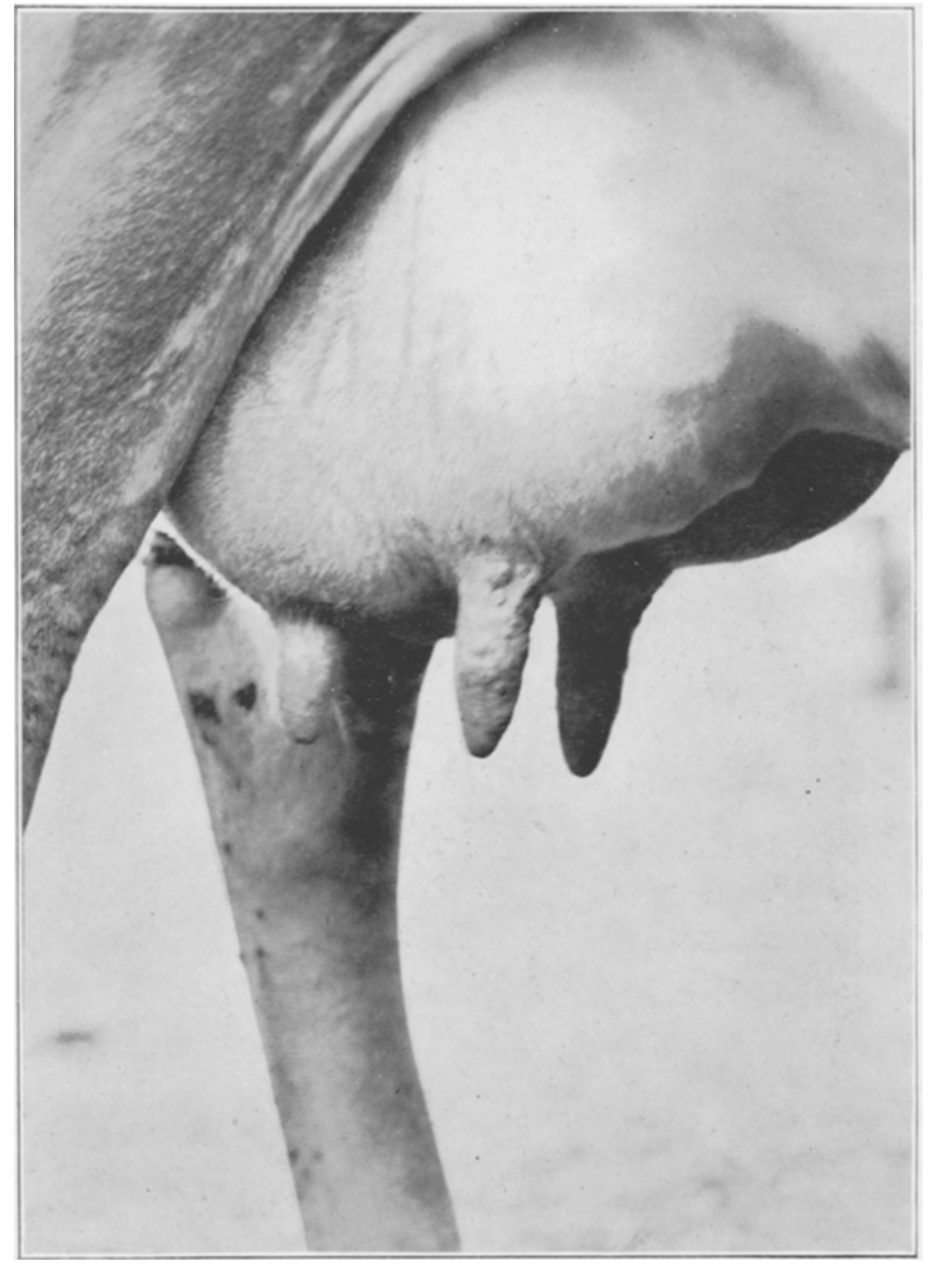

FIG. 5 shows the right side of the udder of another cow whose teats were affected in a less degree. 


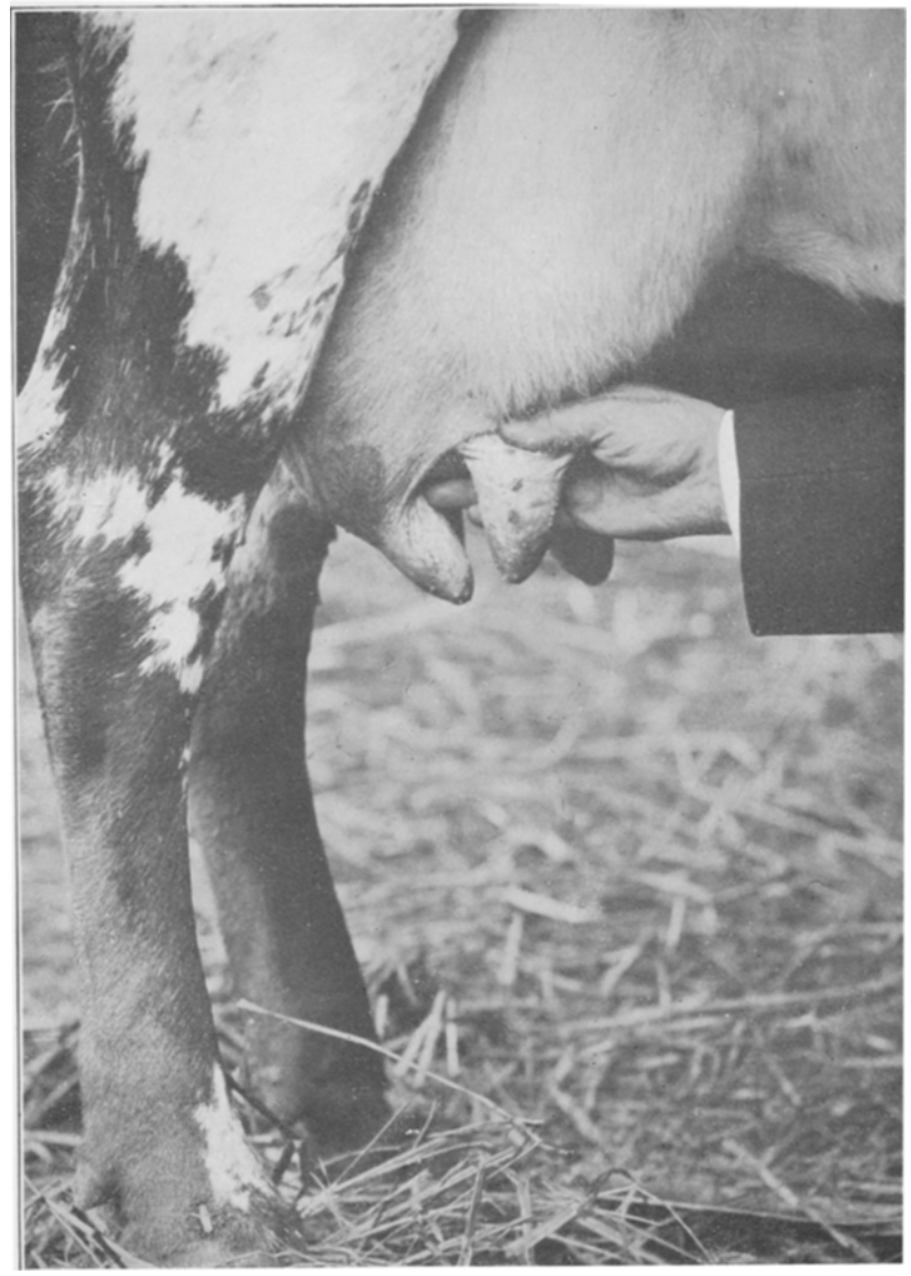

FIG. 6 represents the right side of a cow's udder with the teats slightly affected. 
Meanwhile, as a result of my investigation of the behaviour of the epidemic, having become very suspicious that the infection was milkborne, I had a leaflet printed to the following effect :-

"While it has not been proved that the infection of diphtheria is being spread by milk which is drunk, the present outbreak in Twyford and Ruscombe possesses some of the characteristics of a milk epidemic. It is, therefore, most desirable that all cow's milk, even if taken only in tea or coffee, should be thoroughly boiled before it is drunk. After boiling there need be no hesitation in partaking of milk."

On August 18th I made arrangements for a copy of the leaflet to be distributed by hand to every inhabited house in the two parishes, and that was done on the 19th.

On that day I received reports from the Clinical Research Association to the effect that the diphtheria bacillus could not be found in either of the first two samples of milk which I had sent.

$\mathrm{I}$ obtained permission from $\mathrm{Y}$ and $\mathrm{Z}$ to see their cows with their veterinary attendant, and saw some of $Y$ 's on the 19th and the rest of them and Z's on the 20th.

I found that all the teats of two of Z's cows were badly ulcerated, and that teats of three other cows were affected in a slighter degree. I told Z's wife that I considered the milk from the worst two cows, at any rate, ought not to be sold. She said it should not be, and said she would not make any butter at present.

I obtained permission to see all the cows again with the veterinary attendant and Mr. Mitchell, veterinary surgeon of Reading. On August 21st we examined Z's cows in his presence. Mr. Mitchell agreed with me that the supply of milk from those five cows ought to be stopped. I told $\mathrm{Z}$ so, saying that I had no power or authority to stop the supply, but that I strongly advised him to do so. He endeavoured to arrange for a supply of milk from an entirely different source. I ascertained that the milk from the worst two cows had been kept out of the supply, but that up to the 22nd the milk of the other three had been used. On the 23rd he began to obtain milk from another place.

On the 20 th and 21 st I took swabs from the ulcers on the teats of the worst two cows (Figs. 1, 2, 3, and 4), and forwarded them to the Clinical Research Association for bacteriological examination on the 22 nd. On the 24th I received reports to the effect that suspicious organisms had been cultivated from all the swabs, and I gave directions that everything necessary to fully identify the nature of those organisms was to be done. 
On August 22nd I again examined Y's cows, with the veterinary attendant and $\mathrm{Mr}$. Mitchell. We found six cows affected with an ulcerative condition of the teats, and agreed that they ought to be kept by themselves, and that their milk ought to be kept out of the supply. I saw Y's wife, and strongly advised that that milk should not be sold, and that butter should not be made from it.

I received a report from Mr. Mitchell, of which the following is a copy :-

"On the 21st August, in conjunction with Dr. Ashby, I inspected a herd of cows* at . . Farm, Twyford. I found five to be affected with an 'infective ulcerative' condition of the teats; two cows were badly affected, and three moderately.

"Also, on the 22nd August, in conjunction with Dr. Ashby, I inspected a herd of cowst at . . . Farm, Twyford, and found two cows to be affected with an 'infective ulcerative' condition of the teats, and also on the same day inspected another herd of cows $\dagger$ at ... Farm, Twyford, and found four cows to be affected with an 'ulcerative (infective) ' condition of the teats.

(Signed) "LOUIS MITCHELL, M.R.c.v.s. "per WHEATLEY \& SON."

On the 27th of August I had the udders of four of Z's cows photographed by Mr. Alfred Eustace, of Oxford Road, Reading. The photographs, which are herewith reproduced, give a very good representation of the ulcers on the teats when they were in a healing condition. The ulcers on the other cow had so far healed that I thought the morbid condition would not be shown well in a photograph; but when those of the rest proved to be so distinct, I regretted that I did not have that cow's udder photographed.

The following is extracted from a report on the epidemic which I made to the Rural District Council of Wokingham on Aug. 29th, 1904 :

"I have to-day received a report from the Clinical Research Association stating that they have isolated a suspicious organism from the second sample of Y's milk which I sent to them, and I have instructed them to identify definitely the nature of the organism.

"Swabs from the throats of some of the patients have been examined bacterioscopically, and the diphtheria bacillus has been found in

* Belonging to $\mathrm{Z}$.

+ Belonging to $\mathrm{X}$.

¥ The report stated: "We have isolated from this milk an organism which shows the morphological appearances and staining reactions of the diphtheria bacillus. The above organism is in pure condition, ready for inoculation into an animal, if further culture tests give positive results." 
them. That proves conclusively that the disease which has been epidemic was true diphtheria.

"Taking into consideration all the circumstances of the outbreak, and its unusual behaviour in many respects, there can, I think, be no doubt that it has been a milk epidemic; but whether the infection has been derived from a cow disease remains to be definitely decided.

"I believe the milk influence has now come to an end ; and if due care is taken by the public thoroughly to boil all milk before they consume it, and by the dairymen not to supply any butter or cream from the milk of any suspicious cows, there should be no fear of its being revived; but we must expect that in so many infected houses there will be some further contact cases for a little time to come, while it will not be surprising if a few more dwellings are invaded amongst such a nest of houses as exists in The Grove, Twyford, in four of which the disease has already appeared.

"All school influence, which so frequently is responsible for the spread of diphtheria, can be entirely eliminated, as the schools were shut up for the holidays before the outbreak commenced, and during all the time it has lasted.

"The following conclusions may be deduced from the facts and figures I have given :-

"The outbreak was sudden and continuous, was widely distributed throughout the two parishes, without limitation to any particular parts of them, and appeared to have been due to some common cause acting with scarcely any intermission, while the only thing in common between the two villages and between some of the invaded houses which could be imagined to have carried infection, appeared to have been the milk supply. One of the patients was stated not to have gone outside her garden for twelve months; another had not left his house for five weeks before infection. Two or more persons in the same household were taken ill at the same time, or nearly so, on the first invasion of fourteen houses. That is quite unlike the behaviour of diphtheria when spread through ordinary channels, but is frequently observed in milk-borne epidemics.

"Diphtheria is in the main a children's disease; but in this outbreak only 36 per cent of the patients were under fifteen years of age, and 64 per cent, or not much under two-thirds, of them were above that age, 4 having been over sixty.

"The social position of many of the patients, and the rateable value of the house first invaded, and of many other of the invaded houses, were higher than is often the case when diphtheria is the disease 
concerned. Larger quantities of milk are consumed, and milk is often stored for a longer time in such houses than in those of the purely cottage class, while cream is often taken in them, so their inmates are more likely to be affected by milk-borne infection.

"The incidence of the disease upon the houses supplied by one of the dairymen was especially high.

"Very many of the cases were extremely mild, and the fatality, so far, has been remarkably low, only 1.33 per cent of the attacks. This is quite in keeping with milk-borne diphtheria, which is less severe and less fatal, in most cases, than the usual form of the disease. The early and general use of diphtheria antitoxin which has been practised must, however, have been partially accountable for the extraordinarily low death-rate.

"Thus it will be seen that so many of the characteristics of milk epidemics, which have been so well worked out by Mr. W. H. Power, C.B., F.R.S., the Medical Officer of the Local Government Board, and other observers, are to be found in connection with this outbreak as to warrant the conclusion I have come to concerning its nature.

"Mr. Power was the first to show, in 1878, that diphtheria might be spread by milk, when he clearly proved that that was the channel of infection in an outbreak of diphtheria in North London, but he was unable to discover how it became infected.

"Since then, as stated by Drs. Swithinbank and Newman in their Bacteriology of Milk, more than thirty milk-borne epidemics of diphtheria have been recognized, but there have been recorded only four authentic cases of actual detection of the diphtheria bacillus in ordinary milk, two in 1899, one in 1900, and one in 1901."

After the above was written, an additional reason for assuming the epidemic to have been millk-borne was afforded by its abrupt cessation, with the exception of a few lingering cases, after milk from suspected cows had been withheld from distribution, and printed advice to drink only boiled milk had been distributed throughout the parishes concerned, which advice I had good reason to believe, from numerous enquiries I made personally, was practically universally acted upon; whilst subsequent experience yielded positive assurance of the nature of the disease, inasmuch as six of the patients were affected with various forms of paralysis after their illness, one of the earliest of them in the major epidemic having suffered from very severe general paralysis for over six months. Thus clinical and bacterial proof alike went to show that the disease we had to deal with was true diphtheria. 
On September 24th I received from the Clinical Research Association a report from the Lister Institute of Preventive Medicine, signed by Dr. Alfred MacConkey, on inoculations into guinea-pigs of cultures of the suspicious organisms which had been isolated from the second sample of milk from Y's cows, which I took on August 19th, and from a swab from the ulcers on the teats of one of Z's cows, seen in Figs. 1 and 2, which I took on August 21st.

The inoculation of the culture of the organism from the sample of milk was without any ill-effect upon guinea-pigs. This negative result showed that the growth was not the genuine diphtheria bacillus.

The inoculation into a guinea-pig of 1.5 cubic centimetres of a twenty-four-hours broth culture of the organism which had been isolated from the ulcers on the cow's teats proved pathogenic for guinea-pigs, causing death in forty-eight hours. That the toxicity of this organism could be neutralized by antidiphtheritic serum was shown by the facts:-

1. That 4 cubic centimetres of a twenty-four-hours broth culture mixed with 1 cubic centimetre of antidiphtheritic serum, and injected subcutaneously, gave rise to no ill effect, except a small local swelling ; and

2. That an injection of 3 cubic centimetres of antidiphtheritic serum protected against the subsequent inoculation, twenty-four hours later, with 4 cubic centimetres of a broth culture of the organism.

These results led to the conclusion that the organism from the ulcers on the cow's teats was identical with the diphtheria bacillus, and fully corroborated the conclusion I had arrived at, that the outbreak of diphtheria in Twyford and Ruscombe was a milk-borne epidemic.

Dr. George Dean, Bacteriologist, Serum Department, Lister Institute of Preventive Medicine, has drawn my attention to a paper entitled, "Experiments on the Relation of the Cow to Milk-Diphtheria" by himself and Dr. Charles Todd, late Assistant Bacteriologist in that department, which was published in The Journal of Hygiene, for April, 1902 , in which they describe how they isolated virulent diphtheria bacilli from an eruptive disease of the udders of two cows whose milk had been consumed by persons who suffered from diphtheria, and by others who suffered from sore throat, probably diphtheritic. On September 28th, 1904, he wrote to me from that Institute as follows :-

"I was greatly interested recently by receiving from the Clinical Research Association two cultures of bacilli from milk and udder. They were sent to have the diagnosis of diphtheria bacilli confirmed by animal experiment. . . . The matter is of especial interest to me, 
because Todd and I were the first to isolate the diphtheria bacillus from the udder of cows," as described in the above-named paper, " and this is the only definite confirmation of our observation. It is curious that it should have found its way into my hands. The fact that in the case of the udder it is the genuine diphtheria bacillus was independently arrived at both here and at Chelsea."*

Whether the eruptive disease of the teat was a specific diphtheritic infection of the cow, or whether there was present a specific contagious eruptive condition apart from the diphtheritic infection, cannot now be told ; but certain it is that the diphtheria bacillus was present in the pathological lesions of the cow.

That there was a chance of such an infection having taken place would appear possible from the fact that the cowman who milked Z's cows lived in the house in which the first case of the first outbreak of diphtheria at Twyford occurred in February; for, as Dr. Dean remarks, we now know that apparently healthy individuals are not uncommonly the hosts of the diphtheria bacillus. On the other hand, a bad condition was found in one of the cowsheds, where a watercloset cesspool with a loosely fitting stone cover was discovered hidden by the bedding.

After the milk influence seemed to have been arrested a few cases of diphtheria happened from time to time, as I had anticipated. There were 7 cases in 6 houses at Twyford, 2 on August 27th, 2 in the first week of September, 1 in October, an infant aged two months, who died on the 15th of that month, 1 in November, and 1 on December 13th. The last of those cases and another happened in houses in which there had previously been cases of diphtheria.

There were also 7 cases at Ruscombe, which occurred in 3 houses; 3 of them were in September and 4 were in October.

With a view to preventing spread of infection, 45 London children who had gone to Twyford for a holiday were sent home on August 9th; a flower show and a Band of Hope meeting, which were to have been held on August 10th and 11th respectively, were abandoned; acting on my advice, the Rural District Council gave notice to the managers of the elementary schools in Twyford requiring them to close the schools for three weeks from August 30th, on which day they would have reopened in the ordinary course after the summer holidays; proper disinfection was carried out in the houses on the termination of the cases, by Mr. Street of Reading, who disinfected

${ }^{*}$ Klein had, however, previously inoculated milch cows with the diphtheria bacillus and recovered that growth from eruptions on their udders which followed the inoculations. 
all the bedding, etc., in his steam disinfector; the Council directed $\mathrm{Z}$ to discontinue keeping cows in his sheds, and since then he has kept them at a farm outside the village.

I was told that a few of the London children developed diphtheria after they returned home, but I did not succeed in tracing them.

I am much indebted to Drs. King and Young, of Twyford, Dr. McCrea, of Wargrave, and Dr. Robinson, of Sonning, who attended the patients, for much valuable information respecting the cases which they freely gave me.

The evidence showing that the bacillus isolated from the udder of the cow was a true diphtheria bacillus was obtained by Drs. Dean and MacConkey, of the Lister Institute, working independently, the one at Chelsea, the other at Elstree. It is here given in the form in which they have very kindly supplied it to me, and I tender them my sincerest thanks for their most searching and convincing investigation.

For convenience, the experiments are classified together according to the object of the experiment.

Broth and serum cultures marked " $953 / 8$ from milk";

Broth and serum cultures marked " $992 / 8$ from udder"

were received from the Clinical Research Association for further report. The bacilli in both cases had the morphological and cultural characteristics of the diphtheria bacillus.

\section{Tests on the Milk Organism.}

The broth culture received from the Clinical Research Association was used for inoculation.

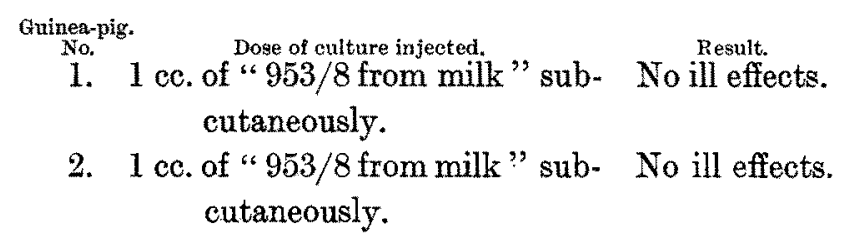

An emulsion of a serum culture made from the broth culture " $953 / 8$ from milk" was used.

2 cc. subcutaneously.

Scarcely any local reaction.

4. 2 cc. intraperitoneally.

No ill effects.

5. 2 cc. alkaline broth culture.

Animal lost no weight; had a local reaction.

6. $2 \mathrm{cc}$. alkaline broth culture $+1 \mathrm{cc}$. The same result; local reantitoxin mixed. action perhaps somewhat smaller. 


\section{Tests on the Udper Organism.}

The broth culture received from the Clinical Research Association was used for inoculation.

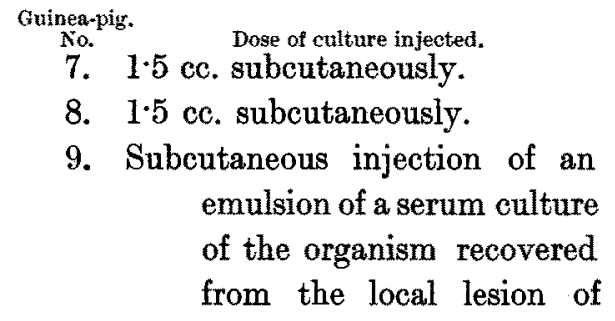

Tubes inoculated from heart-blood remained sterile.

Experiments showing the Protective Effect of Antitoxin agarnst Infection with the Living Culture.

A twenty-four-hours broth culture made from the original serum culture (992/8 udder) received from the Clinical Research Association was used for inoculation.

No. Dose of culture injected.

10. 2 ce. subcutaneously. Died second day. Died sixth day.

11. 4 cc. subcutaneously. Died second day.

12. 2 cc. culture +1 cc. serum Very slight local reaction. subcutaneously.

13. 4 cc. culture +1 cc. serum. Very slight local reaction.

14. $3 \mathrm{cc}$. serum and 20 hours later No ill effects.

\section{4 cc. culture (24-hours} broth).

Six cc. of diphtheria antitoxin were injected into a guinea-pig, and two days later 2 cc. of an alkaline broth culture (udder 48 hours) were injected into this prepared guinea-pig and into a control guineapig. The prepared guinea-pig lived, the control died on the third day.

Guinea-pig. Weight
No.

15. $300 \quad 6$ cc. antitoxin, 17. ix. $04+2 \mathrm{cc}$.

alkaline broth culture 19.ix.04 Lived.

16. 3002 ce. alkaline broth culture Died third day.

Preparation of Toxin.

Estimation of the minimal lethal dose, and neutralization of toxin by antitoxin.

The bacillus isolated from the cow's udder was planted on alkaline 
broth, grown for ten days, and filtered through a Berkefeld filter. The filtrates tested on guinea-pigs gave the result shown in the Table :-

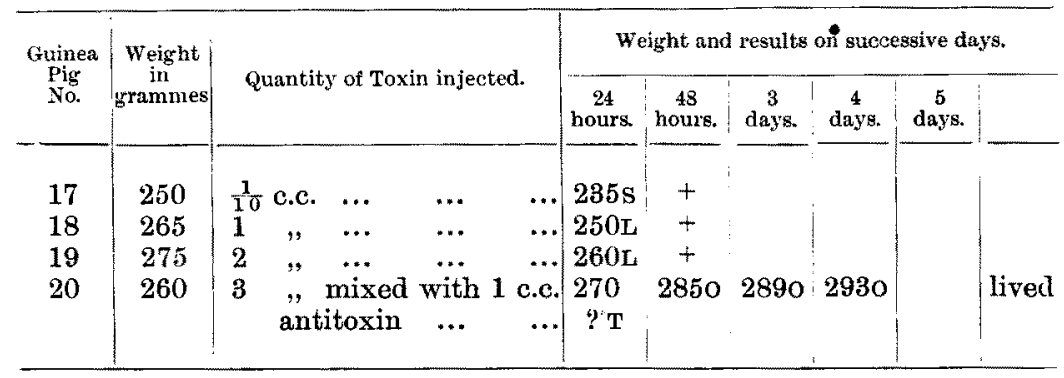

A further test was carried out with a second filtrate of the bacillus from udder, with the result shown in the Table :-

\begin{tabular}{|c|c|c|c|c|c|c|c|c|}
\hline \multirow{2}{*}{$\begin{array}{c}\text { Guinea } \\
\text { Pig } \\
\text { No. }\end{array}$} & \multirow{2}{*}{$\begin{array}{c}\text { Weight } \\
\text { in } \\
\text { grammes }\end{array}$} & \multirow{2}{*}{ Quantity of Toxin infected. } & \multicolumn{6}{|c|}{ Weight and results on successive days } \\
\hline & & & $\begin{array}{c}24 \\
\text { hours. }\end{array}$ & $\begin{array}{c}48 \\
\text { hours. }\end{array}$ & $\begin{array}{c}3 \\
\text { dayss. }\end{array}$ & $\begin{array}{c}4 \\
\text { days. }\end{array}$ & $\begin{array}{c}5 \\
\text { days. }\end{array}$ & $\begin{array}{c}6 \\
\text { days. }\end{array}$ \\
\hline 21 & 245 & $\frac{1}{20}$ c.c. & $220 \mathrm{M}$ & + & & & & \\
\hline 22 & 245 & $\frac{1}{40} \eta$ & $220 \mathrm{M}$ & + & & & & \\
\hline 23 & 225 & $\frac{1}{80}$, & $210 \mathrm{~s}$ & $210 M$ & $210 \mathrm{M}$ & $210 \mathrm{~L}$ & $200 \mathrm{u}$ & $200 \mathrm{~L}$ \\
\hline 24 & 220 & $\frac{1}{100}$, & $210 \mathrm{M}$ & $200 \mathrm{M}$ & $235 \mathrm{M}$ & $240 \mathrm{M}$ & $235 \mathrm{M}$ & $240 \mathrm{M}$ \\
\hline 25 & 225 & $\frac{1}{320}$, & $220 \mathrm{~s}$ & $235 \mathrm{M}$ & $230 \mathrm{M}$ & $240 \mathrm{M}$ & $240 \mathrm{M}$ & $250 \mathrm{M}$ \\
\hline
\end{tabular}

The post-mortem appearance in the case of all the animals dying as the result of inoculation with the udder bacillus or its toxin presented in a more or less marked degree the characteristics usually associated with diphtheria toxæmia; subcutaneous œdema, in certain cases hæmorrhagic, at the site of inoculation; congestion of viscera, especially of the suprarenal glands, and fluid in the pleural and peritoneal cavities.

From these experiments we see :-

1. That the bacillus isolated from the milk was a diphtheroid bacillus, perhaps an avirulent diphtheria bacillus.

2. That the diphtheria-like bacillus isolated from the udder of the cow was virulent for the guinea-pig.

3. That the post-mortem changes were characteristic of diphtheria toxæmia.

4. That the bacillus produced a toxin of which $\frac{1}{40} \mathrm{cc}$. killed a guinea-pig of 245 grammes in 48 hours. The bacillus was, therefore, of moderate toxigenic power. 
5. That diphtheria antitoxin, when given along with, or even 24 to 48 hours before, inoculation with single or multiple lethal doses of living culture, protected the guinea-pigs.

6. That diphtheria antitoxin was capable of neutralizing at least 30 minimal lethal doses of toxin.

We are, therefore, justified in concluding that the bacillus isolated from the udder was a true Klebs-Löffler bacillus.

December 7 th, 1905.

Contiguous to the two parishes already dealt with is the extensive parish of Hurst St. Nicholas, which at the census of 1901 had a widely distributed population of 1,006 persons, living in 235 houses.

Hurst suffered badly from diphtheria, in a lingering fashion, from the latter part of April, 1904, to January, 1905.

On April 25th two cases were notified in one of two semi-detached cottages standing quite by themselves; on the 26 th there was a case in the other of those two houses; on May 2nd there was a third case in the first-named house, and on the 12th there was a second case in the other. There was then not another case until June 5th, when there was a third case in that house. Ten days later another house was invaded, but, be it observed, not until fifty days had elapsed since the disease first appeared in the second house. Then followed invasions of houses at irregular, and in manv cases prolonged intervals, right on till January, 1905. From the beginning to the end of the outbreak there were 31 cases in 23 houses in the parish. Two of the patients died, a girl aged four on August 13th, and a girl aged eleven on August 17th.

A glance at the following table will show at once how different was the behaviour of this Hurst outbreak, as regards suddenness and continuity of attack, from that of the Twyford and Ruscombe outbreak :-

\begin{tabular}{|c|c|c|c|c|c|}
\hline \multirow{2}{*}{\multicolumn{2}{|c|}{$\begin{array}{l}\text { Date. } \\
1904 . \\
\text { April } 25\end{array}$}} & \multicolumn{2}{|c|}{$\begin{array}{l}\text { Number of } \\
\text { Houses first invaded. }\end{array}$} & \multicolumn{2}{|c|}{$\begin{array}{l}\text { Number of } \\
\text { Persons attacked. }\end{array}$} \\
\hline & & $\ldots$ & 1 & . & 2 \\
\hline " & 26 & . & 1 & . & 1 \\
\hline May & 2 & $\ldots$ & 0 & . & 1 \\
\hline " & 12 & $\ldots$ & 0 & . & 1 \\
\hline June & 5 & . & 0 & . & 1 \\
\hline " & 15 & . & 1 & $\ldots$ & 1 \\
\hline , & 24 & $\ldots$ & 1 & . & 1 \\
\hline$"$ & 28 & $\ldots$ & 1 & .. & 1 \\
\hline July & 15 & $\ldots$ & 2 & . & 2 \\
\hline
\end{tabular}




\begin{tabular}{|c|c|c|c|c|c|c|}
\hline \multirow{2}{*}{$\begin{array}{l}\text { Date. } \\
\text { Aug. }\end{array}$} & \multirow[b]{2}{*}{4} & \multirow{2}{*}{\multicolumn{2}{|c|}{$\begin{array}{l}\text { Number of } \\
\text { Houses flrst invaded. }\end{array}$}} & \multicolumn{3}{|c|}{$\begin{array}{l}\text { Number of } \\
\text { Persons attacked. }\end{array}$} \\
\hline & & & & . & 2 & Schools \\
\hline " & 6 & . & 0 & $\ldots$ & 1 & closed from \\
\hline, & 8 & $\cdots$ & 1 & . & 11 & July 19 th to \\
\hline , & 25 & $\ldots$ & 0 & . & 1) & Sept. 4th. \\
\hline Sept. & 28 & . & 1 & .. & 1 & \\
\hline Oct. & 14 & . & 0 & . & 1 & \\
\hline , & 26 & . & 1 & . & 1 & \\
\hline & 28 & . & 1 & . & 1 & \\
\hline Nov. & 1 & . & 1 & . & 1 & \\
\hline , & 9 & . & 1 & . & 1 & \\
\hline & 16 & . & 1 & . & 1 & \\
\hline Dec. & 20 & $\because$ & 1 & . & 1 & \\
\hline ", & 24 & $\cdots$ & 1 & . & 1 & \\
\hline$"$ & 28 & . & 1 & . & 1 & \\
\hline$" 1905$ & 31 & . & 1 & . & 1 & \\
\hline Jan. & 7 & $\cdots$ & 1 & $\ldots$ & 1 & \\
\hline$"$ & 12 & . & 0 & . & 1 & \\
\hline " & 15 & . & 1 & . & 1 & \\
\hline ", & 16 & $\cdots$ & 1 & . & 1 & \\
\hline & & & 23 & & $\overline{31}$ & \\
\hline
\end{tabular}

With the exception of five adults, all the patients were children under fifteen years of age; so 83.9 per cent of them were under that age, whilst only $16 \cdot 1$ per cent were over fifteen; the corresponding numbers in the Twyford and Ruscombe outbreak having been 36 and 64 respectively. Most of the patients were living in houses of the cottage type. There was no marked incidence of the disease on houses supplied with any particular milk. There was a multiple attack in the house first invaded, but there was only one other multiple attack, and that was more than three months later. The outbreak throughout the parish was not sudden, nor was it continuous; it did not end abruptly, but lingered on, with several prolonged intervals, into the early part of 1905 . Most of the children attacked when the houses were first invaded were attending Hurst girls and infants' school. In addition to that, children living in a house on the extreme edge of the parish of Ruscombe, in which the disease broke out in October, and others living in two houses at Winnersh, in which it appeared in November, there being no other houses invaded in that parish, were also attending school at Hurst. All the early 
cases occurred amongstyoung children; no adults were attacked untilone was on August 4th, and one on November 1st, and it was not until the fag end of the outbreak in January, 1905, that the other three adults, one of whom was a district nurse, fell ill. The schools were closed on July 19th, and remained so during the summer holidays, until September 4th, 1904; the girls and infants' school was thoroughly disinfected. Three fresh houses were invaded in August, but none were during the fifty days between the 8 th of that month and the 28 th of September.

All this was unlike, and did not suggest the idea of, a milk-borne epidemic. The outbreak appeared rather to have been due to a succession of cases caused by contact, in some way or other; and I strongly suspected that that was brought about in many instancesthough not of course in all-through the attendance of children at the girls and infants' school. Probably there were unrecognized mild cases of diphtheria which escaped medical treatment but were capable of imparting infection.

I have given this brief outline of the Hurst outbreak, because it seems to me that the contrast it affords brings out in bold relief the exceptional behaviour of the Twyford and Ruscombe epidemic.

NoTE.-From recent experience, gained by extensive bacterioscopic examination of swabs from school children during prevalence of diphtheria elsewhere, I now feel convinced that the lingering continuance of the disease at Hurst was mainly due to convalescents and contacts having been carriers of the diphtheria bacillus for prolonged periods.

The Committee on Industrial Diseases.-The Departmental Committee which was appointed to "enquire and report what diseases and injuries, other than injuries by accident, are due to industrial occupations, are distinguishable as such, and can properly be added to the diseases enumerated in the Third Schedule of the Workmen's Compensation Bill, 1906," has begun its enquiry. The Committee proposes to investigate the following diseases and injuries which have been suggested for its consideration, viz., gradual poisoning from the vapour of carbon disulphide, dinitrobenzol, dinitrotoluol, and anilin; gradual poisoning from carbonic oxide gas, sulpheretted hydrogen gas, and chlorine gas; alkaloidal poisoning from African boxwood in shuttlemaking; illness set up by nitrous fumes, hydrochloric acid fumes, ammonium chloride fumes, and sulphur fumes; compressed air illness (caisson disease); chrome ulceration of the skin; various trade eczemas; fibrosis of the lungs from inhalation of silicious or metallic particles (potter's asthma and grinder's phthisis); pneumonia from inhalation of basic slag dust; miner's nystagmus and miner's "beat knee" and "beat hand"; neurosis due to vibration; cardiac dilatation in slate quarries; and glanders. Correspondence relating to the enquiry should be addressed to Frank Elliott, Esq., secretary to the Committee, at the Home Office, Whitehall, S.W. Anthrax, ankylostomiasis, and poisoning by lead, mercury, phosphorus, and arsenic are already included in the Third Schedule of the Workmen's Compensation Bill, and are not, therefore, within the Committee's terms of reference. 